\title{
Structural Performance of Finger-Jointed Lumber with Different Joint Configurations*1
}

\author{
Sang-Joon Lee*2, Chang-Deuk Eom², and Kwang-Mo Kim²†
}

\begin{abstract}
Three different finger-jointed lumbers which have different geometric features and adhesives were manufactured and studied in this study. Larch and pitch pine lumbers with and without preservative treatment were used. Bending MOE was measured as the preliminary investigation for grouping the specimen. After the finger, bending MOE of two wood species without preservative treatment shows over $97 \%$ property of the control group. The tensile modulus also shows almost same property after the finger joint. And it is found out that the preservative treatment induce little effect on bending and tensile MOE. Based on this result, high performance of examined finger-jointed lumber can be found out. However, tensile strength decreased around $20 \%$ which would be induced by the crack along the root of the finger which is formed near the edge during manufacturing stage. And finger-jointed lumber with preservative treatment even shows higher decrement of the tensile strength with higher wooden part failure mode.
\end{abstract}

Keywords: finger-jointed lumber, preservative treatment, MOE, tensile modulus, tensile strength

\section{INTRODUCTION}

There are several methodologies for connecting laminar along the longitudinal direction. And the finger joint has been widely applied because of its high workability and efficiency with the high production yield (Byeon et al., 1997; Ryu et al., 2004). It has been widely used as the structural and non-structural applications for increasing the length of the member and avoiding unwanted defects which induce the value-added product. Additionally, recent rising concern about the large span wooden structure would make more needs on the finger joint method.

Many researches have been conducted to find out the optimum geometry of the finger joint (Hong et al., 2000; Byeon et al., 2001; Ryu et al., 2003), effect of the applied adhesives (Shaler et al., 1988; Lawrence and Jerrold, 1989; So and Chai, 2005), changes in mechanical properties due to the finger joint (Eby, 1981; Kim and Lee, 2000; Ozcifci and Yapici, 2008), evaluation and prediction on structural perfor-

*1 Received on March 2, 2011; accepted on March 14, 2011

*2 Division of Wood Engineering, Department of Forest Resources Utilization, Korea Forest Research Institute, Seoul 130-712, Korea

† Corresponding author : Kwang-Mo Kim (e-mail: lovewood@forest.go.kr) 
Table 1. Specification of the tested specimen

\begin{tabular}{ccccc}
\hline & & Larch & $\begin{array}{c}\text { Pitch } \\
\text { Pine }\end{array}$ & $\begin{array}{c}\text { CuAz-3 } \\
\text { Pitch Pine }\end{array}$ \\
\hline \hline $\begin{array}{c}\text { Number of } \\
\text { specimens }\end{array}$ & (EA) & 80 & 60 & 56 \\
& (EA/group) & 20 & 15 & 14 \\
\hline & Control & 10,854 & 8,589 & 8,873 \\
Average & Group A & 10,863 & 8,576 & 8,843 \\
MOE & Group B & 10,862 & 8,516 & 8,815 \\
(MPa) & Group C & 10,869 & 8,598 & 8,836 \\
& Average & 10,862 & 8,570 & 8,842 \\
\hline
\end{tabular}

mance of the glulam which have finger-jointed lumber (Park and Hong, 2001; So, 2007) and so on. Many of these findings offer the effective production of finger-jointed lumber and glulam. Therefore, it is expected that many manufacturers applied these findings to make commercially produced finger-jointed lumber. However, many researches limited to find out the specific factors affecting the performance of the finger- jointed lumber. Even except the above-mentioned factors, the overall research which can analyze the performance of the finger-jointed lumber should be performed including the species of wood, whether or not the lumber treated with preservatives, finger at wide and narrow face, and so on.

In this study, the structural performance of the commercially manufactured finger joint was examined. Structural performance based on the bending and tensile property was investigated as the finger-jointed lumber can be used for the structural use. Finger geometry in terms of the adhesion area and differences in width of top and root were considered. Additionally, effect of preservative treatment on the structural performance of the lumber was investigated.

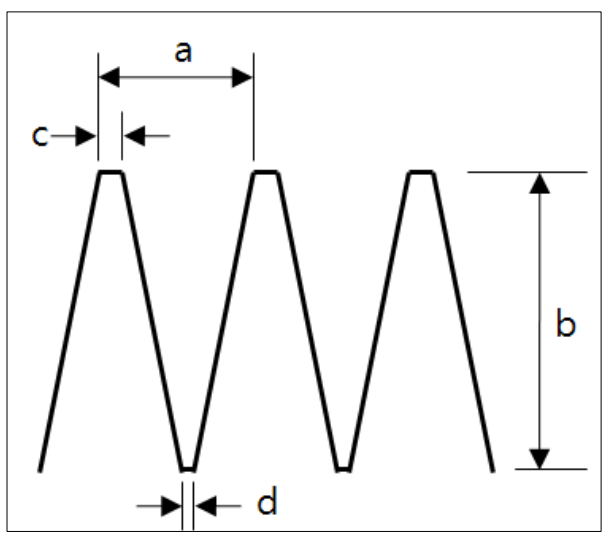

Fig. 1. Measured size of the finger.

\section{MATERIALS and METHODS}

\subsection{Materials}

2 by $6(35 \mathrm{~mm} \times 138 \mathrm{~mm} \times 3,600 \mathrm{~mm})$ lumbers with two wood species (Larch, pitch pine and pitch pine treated with $C u A z-3$ named as $\mathrm{CuAz}-3$ pitch pine) were prepared. Specimens were targeted to kiln-dried to reach $15 \%$ moisture content. In the case of the $\mathrm{CuAz}-3$ pitch pine, specimens were treated with the preservative due to hazard class of $\mathrm{H} 3$ (Korea Forest Research Institute notification 2009-07). And bending MOE was measured as the preliminary investigation of this study (see also chap. 2.3), and then lumbers were grouped (four groups - control and three groups which will be finger-jointed at different three manufacturers) to have almost same average MOE (Table 1). Total number of each group of specimens were 80, 60 and 56 for larch, pitch pine and $\mathrm{CuAz}-3$ pitch pine respectively.

\subsection{Manufacture of the Finger Joint}

Finger joint was manufactured from three different Korean manufacturers. Finger joint was made at the middle part of the lumber 
Sang-Joon Lee, Chang-Deuk Eom, and Kwang-Mo Kim

Table 2. Manufacturing condition of the finger joint with three different types

\begin{tabular}{|c|c|c|c|}
\hline Manufacturer & A & B & $\mathrm{C}$ \\
\hline Manufactured face & Wide face & Wide face & Narrow face \\
\hline Number of the finger & 22 & 22 & 4 \\
\hline Pitch, a & 6.24 & 6.23 & 6.49 \\
\hline Length, $b$ & 19.75 & 19.46 & 23.64 \\
\hline Tip width, c & 1.39 & 1.36 & 1.17 \\
\hline Root width, d & 0.61 & 0.95 & 1.17 \\
\hline Adhesive area $\left(\mathrm{cm}^{2}\right)$ & 310.73 & 306.64 & 262.04 \\
\hline Adhesive & Resorcinol-phenol & Polyvinyl acetate & Resorcinol-phenol \\
\hline Photograph & 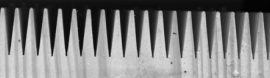 & ||||||||||||||||| & \\
\hline
\end{tabular}

without visible knots and other defects. Manufactured size such as pitch, length and tip and root width was measured and geometry which includes the adhesive area were measured (Table 2). Resorcinol-phenol was used for group $\mathrm{A}$ and $\mathrm{C}$ while polyvinyl acetate was used for group B.

\subsection{Measurement of the Edgewise Bending MOE}

Continuous MOE measuring equipment (5 kN; Dryingeng Co. Ltd., Gwangju, Korea) was used for measuring the edgewise bending MOE. The equipment was designed to meet the requirements of Korean standard $(K S \quad F$ 3021-2005). A center-point load was applied with $3 \mathrm{~m}$ of simple span of the specimen and the cross-head speed was $10 \mathrm{~mm} / \mathrm{min}$. Induced load was measured by imposing a midspan deflection of $5 \mathrm{~mm}$. The MOE results from two opposite faces were averaged.

\subsection{Measurement of the Tensile Properties}

Tensile properties including tensile modulus and strength were measured with the tension testing machine (1 MN; Kyoung Sung Testing Machine Co. Ltd., Ansan, Korea) with 600-mmlong grips and $2 \mathrm{~mm} / \mathrm{min}$ cross-head speed. The 3600-mm-long specimens were centered in the testing machine so that the middle $1 \mathrm{~m}$ could be subjected to uniform tensile stress. The displacement was measured by two LVDTs at $40-\mathrm{kN}$ tensile load for measuring the tensile modulus. The LVDT were centered on the opposite wide faces at midspan. Tensile modulus was determined from the average displacement measured by the two LVDTs at a target load level. The tensile load was applied till the failure of the specimen for determining the tensile strength. And the failure mode was checked with naked eye.

\section{RESULTS and DISCUSSION}

\subsection{MOE}

Measured MOE is described at Table 3. Average MOEs of control specimens show 10,320 $\mathrm{MPa}, 8,110 \mathrm{MPa}$ and 8,540 $\mathrm{MPa}$ for larch, pitch pine and $\mathrm{CuAz}-3$ pitch pine 
Structural Performance of Finger-Jointed Lumber with Different Joint Configurations

Table 3. Average MOE of the control and manufactured groups for larch, pitch pine and CuAz-3 pitch pine

\begin{tabular}{ccccccccc}
\hline & \multicolumn{2}{c}{ Larch } & & \multicolumn{2}{c}{ Pitch pine } & & \multicolumn{2}{c}{ CuAz-3 pitch pine } \\
\cline { 2 - 3 } & MOE (MPa) & Ratio (\%) & & MOE (MPa) & Ratio (\%) & & MOE (MPa) & Ratio (\%) \\
\hline \hline Control & 10,320 & 100 & & 8,110 & 100 & & 8,540 & 100 \\
\hline Group A & 10,050 & 97 & & $8,140^{*}$ & 100 & 8,160 & 96 \\
Group B & 9,790 & 95 & & 7,670 & 95 & & 8,060 & 94 \\
Group C & $10,130^{* *}$ & 98 & & 8,130 & 100 & & 8,130 & 95 \\
\hline $\begin{array}{c}\text { Average of Group A, B } \\
\text { and C }\end{array}$ & 9,990 & 97 & & 7,980 & 98 & 8,110 & 95 \\
\hline
\end{tabular}

* Failure occurred by mis-operation of test machine for one specimen.

** Glue line failure due to inadequate production for four specimens.

※ Failed specimens were excluded for calculation the average MOE.

respectively. The MOE difference around $5 \%$ of control specimens in Table 1 and 3 seemed to induced by the change of moisture content after drying. Unfortunately, the moisture content just after drying process was not checked, and it was deduced that the specimen had been over-dried (lower MC at Table 1). For finding out the exact effect of before and after the finger joint, average MOEs of each group were compared with that of the control group.

Average MOEs of the group B which uses the polyvinyl acetate show about $5 \sim 6 \%$ reduction compared with that of the control group. However, it is not significant decrement compared with previous reports (Byeon et al., 2001; Ryu et al., 2003). Around 2 3\% percent of MOE was decreased after the finger. And four specimens which have the glue line failure at the manufacturing process for larch of the group $\mathrm{C}$ were excluded and this would be due to zero value of the tolerance ('c' - 'd' of Table 2). Excepting these specimens, high adhesion performance was found out even the adhesive area is about $85 \%$ of other two groups.

It is also confirmed that the preservative treatment with $\mathrm{CuAz}-3$ induces almost same MOE. MOEs of pitch pine with and without preservative treatment show $8,110 \mathrm{MPa}$ and $8,540 \mathrm{MPa}$ respectively. Around $5 \%$ of $\mathrm{MOE}$ decreased after the finger joint for the $\mathrm{CuAz}-3$ pitch pine and is slightly higher decrement compared with the non-treated pitch pine $(2 \%)$.

\subsection{Tensile Properties}

Tensile modulus and tensile strength of finger joint lumbers were measured (Table 4). Same as the bending MOE, decrement ratio was calculated to consider the effect of finger joint based on the property of the control group. Tensile modulus of three control groups show 14.05 GPa, 11.53 GPa and 11.90 GPa for larch, pitch pine and $\mathrm{CuAz}-3$ pitch pine respectively. Tensile modulus of three groups show almost same and/or even increased value compared with that of the control group. The increment of the tensile modulus would be induced by the adhesive layer which have relatively higher stiffness.

Specimens with preservative treatment also shows almost same tensile modulus after the finger $(101 \%$ of the control group for pitch pine with and without the preservative treatment). This indicates that the bending and tensile 
Sang-Joon Lee, Chang-Deuk Eom, and Kwang-Mo Kim

Table 4. Tensile roperties of the control and manufactured groups for larch, pitch pine and CuAz-3 pitch pine

\begin{tabular}{|c|c|c|c|c|c|c|}
\hline & \multicolumn{3}{|c|}{ Tensile modulus (GPa) } & \multicolumn{3}{|c|}{ Tensile strength $(\mathrm{MPa})$} \\
\hline & $\begin{array}{c}\text { Larch } \\
\text { (Ratio (\%)) }\end{array}$ & $\begin{array}{l}\text { Pitch pine } \\
\text { (Ratio (\%)) }\end{array}$ & $\begin{array}{c}\text { CuAz-3 pitch } \\
\text { pine } \\
\text { (Ratio (\%)) }\end{array}$ & $\begin{array}{c}\text { Larch } \\
\text { (Ratio (\%)) }\end{array}$ & $\begin{array}{l}\text { Pitch pine } \\
\text { (Ratio (\%)) }\end{array}$ & $\begin{array}{c}\text { CuAz-3 pitch } \\
\text { pine } \\
\text { (Ratio (\%)) }\end{array}$ \\
\hline Control & $\begin{array}{l}14.05 \\
(100)\end{array}$ & $\begin{array}{l}11.53 \\
(100)\end{array}$ & $\begin{array}{l}11.90 \\
(100)\end{array}$ & $\begin{array}{l}25.9 \\
(100)\end{array}$ & $\begin{array}{c}24.2 \\
(100)\end{array}$ & $\begin{array}{l}25.8 \\
(100)\end{array}$ \\
\hline Group A & $\begin{array}{l}14.77 \\
(105)\end{array}$ & $\begin{array}{l}11.75 \\
(102)\end{array}$ & $\begin{array}{l}11.58 \\
(97)\end{array}$ & $\begin{array}{l}20.6 \\
(80)\end{array}$ & $\begin{array}{l}20.7 \\
(86)\end{array}$ & $\begin{array}{l}19.5 \\
(76)\end{array}$ \\
\hline Group B & $\begin{array}{l}14.00 \\
(100)\end{array}$ & $\begin{array}{l}11.17 \\
(97)\end{array}$ & $\begin{array}{l}12.15 \\
(102)\end{array}$ & $\begin{array}{l}22.1 \\
(85)\end{array}$ & $\begin{array}{l}19.0 \\
(79)\end{array}$ & $\begin{array}{l}19.3 \\
(75)\end{array}$ \\
\hline Group C & $\begin{array}{l}14.67 \\
(104)\end{array}$ & $\begin{array}{l}11.88 \\
(103)\end{array}$ & $\begin{array}{l}12.00 \\
(101)\end{array}$ & $\begin{array}{l}20.1 \\
(78)\end{array}$ & $\begin{array}{l}20.4 \\
(84)\end{array}$ & $\begin{array}{l}17.1 \\
(66)\end{array}$ \\
\hline $\begin{array}{c}\text { Average of Group } \\
\text { A, B and C }\end{array}$ & $\begin{array}{l}14.48 \\
(103)\end{array}$ & $\begin{array}{l}11.60 \\
(101)\end{array}$ & $\begin{array}{l}11.91 \\
(101)\end{array}$ & $\begin{array}{l}20.9 \\
(81)\end{array}$ & $\begin{array}{l}20.0 \\
(83)\end{array}$ & $\begin{array}{l}18.6 \\
(72)\end{array}$ \\
\hline
\end{tabular}
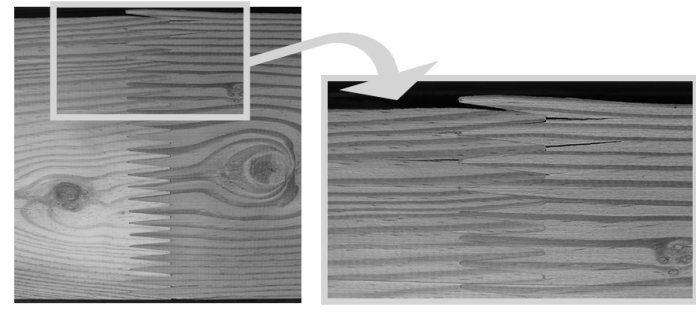

Fig. 2. Cracks along the root of the finger joint.

modulus would not seriously affected by preservative treatment throughout proper treat process.

Tensile strength of control groups show 25.9 $\mathrm{MPa}, 24.2 \mathrm{MPa}$ and $25.8 \mathrm{MPa}$ for larch, pitch pine and CuAz-3 pitch pine respectively. Comparing with the MOE and tensile modulus, tensile strength drops down dramatically from 14 to $34 \%$ for each group. This significant strength reduction would be induced because of the crack along the root of the finger which is formed near edge during the manufacturing process (Fig. 2).

The failure mode which differentiates the tensile failure at the wooden part or the finger-jointed part was checked with naked eye and around 41, 48 and $60 \%$ of test specimen for larch, pitch pine and $\mathrm{CuAz}-3$ pitch pine shows failure at the wooden part. Table 5 shows the tensile strength of finger-jointed lumber divided by the failure mode. The tensile strength decreased about 15 and $9 \%$ for the lumbers which failed at the jointed part while about 25 and $27 \%$ were decreased for the lumbers which failed at the wooden part. The above-mentioned crack would induce the failure at the wooden part which makes overall strength loss around 20\%. Therefore, it is considered that the failure at the wooden part which would be induced by the crack cause even serious strength reduction while finger joint itself makes less than $15 \%$ of tensile strength reduction.

The average strength decrement of the finger-jointed lumber with preservative treatment (CuAz-3 pitch pine) shows much lower value of $72 \%$. Especially, the strength of the specimens which failed at the wooden part $(60 \%$ of failure 
Structural Performance of Finger-Jointed Lumber with Different Joint Configurations

Table 5. The tensile strength due to the failure mode for larch, pitch pine and CuAz-3 pitch pine

\begin{tabular}{cccccccc}
\hline & \multicolumn{2}{c}{ Larch } & & \multicolumn{2}{c}{ Pitch pine } & & \multicolumn{2}{c}{ CuAz-3 pitch pine } \\
\cline { 2 - 3 } & $\begin{array}{c}\text { Tensile } \\
\text { strength (MP) }\end{array}$ & Ratio (\%) & $\begin{array}{c}\text { Tensile } \\
\text { strength (MP) }\end{array}$ & Ratio (\%) & $\begin{array}{c}\text { Tensile } \\
\text { strength (MP) }\end{array}$ & Ratio (\%) \\
\hline \hline Control & 25.9 & 100 & 24.2 & 100 & 25.8 & 100 \\
\hline $\begin{array}{c}\text { Failure at finger } \\
\text { joint }\end{array}$ & 21.9 & 85 & 22.1 & 91 & 21.7 & 84 \\
$\begin{array}{c}\text { Failure at wooden } \\
\text { part }\end{array}$ & 19.3 & 75 & 17.7 & 73 & 16.4 & 64 \\
\hline Average & 20.9 & 81 & 20.0 & 83 & 18.6 & 72 \\
\hline
\end{tabular}

mode for $\mathrm{CuAz}-3$ pitch pine) shows serious decrement $(64 \%)$ and this also would be occurred by the above-mentioned crack. So, it seems that the preservative treatment would raise up the frequency of the presence of the crack which induce the failure at the wooden part even with the well-known pre-hardening effect of preservatives. Therefore, the performance of the finger-jointed lumber especially the preservative treated lumber should be carefully considered at the manufacturing stage.

\section{CONCLUSIONS}

Mechanical properties of commercially manufactured three type of finger-jointed lumber were investigated. Bending and tensile modulus show almost same value after the finger joint. In the case of the bending MOE, $5 \sim 6 \%$ of reductions in property occurred which uses polyvinyl acetate as the adhesive. And high performance was found out for the fingerjointed lumber at the narrow face even the adhesive area is about $85 \%$ of other groups. In the case of the tensile modulus, there is little differences by the species, whether or not the lumber treated with the preservative. Differ from the bending and tensile modulus, tensile strength shows around $20 \%$ reduction after the finger. Failure at the wooden part due to the crack along the root of the finger would be the reason for strength reduction. The manufacturing process need to be more carefully considered about the cracks along the root of the finger especially for the preservative treated lumber.

\section{REFERENCES}

1. KFRI notification 2009-07. Korea Forest Research Institute.

2. KS 2005. Structural glued laminated timber. KS F 3021, Korean Stands Association.

3. Byeon, H. S., H. M. Park, and J. M. Kim. 1997. Improvement of Bending Performances by Sloped Finger-Joint Method in Pinus densiflora S. et Z. (I). Mokchae Konghak 25(4): $61 \sim 67$.

4. Byeon, H. S., H. S. Ryu, and S. R. Ahn. 2001. Effect of Finger Dimensions of Tip and Root Widths on Bending Strength Properties. Journal of Korea Furniture Society 12(2): 1 10.

5. Eby, R. E. 1981. Proofloading of finger-joints for glulam timber. Forest Prod. J. 31(1): $37 \sim 41$.

6. Hong, B. W., H. S. Byeon, and J. M. Kim. 2000. The Effect of Finger Length on Bending Strength Properties in Laminated Wood. Journal of Korea Furniture Society 11(2): 7 12.

7. Kim, G. C. and J. J. Lee. 2000. Effects of Finger Joint and Strength of Lamination on the Estimation of Strength Properties of Glulam. 
Mokchae Konghak 28(1): 8 17.

8. Lawrence, A. S. and E. W. Jerrold. 1989. Long-term strength of CCA-treated lumber. Forest Prod. J. 39(5): $64 \sim 68$.

9. Ozcifci, A. and F. Yapici. 2008. Structural performance of the finger-jointed strength of some wood species with different joint configurations. Construction \& building materials. 22(7): $1543 \sim 1550$.

10. Park, J. C. and S. I. Hong. 2001. Strength properties of arch type laminated lumber produced from domestic small lumbers. J. Kor. For. En. 20(1): $73 \sim 80$.

11. Ryu, H. S., S. Y. Ahn, H. M. Park, H. S. Byeon, and J. M. Kim. 2004. Effect of Distance between Finger Tip and Root Width on Compressive Strength Performance of Finger-Jointed Timber. Mokchae Konghak 32(4): 66 73.

12. Ryu, H. S., S. Y. Ahn, G. P. Lee, H. M. Park, and H. S. Byeon. 2003. The Bending Strength Properties and Acoustic Emissions to the Difference of Finger Widths. Mokchae Konghak 31(2): $84 \sim 91$.

13. Shaler, S. M., B. Wright, and B. Harvey. 1988. Strength and durability of phenol-resorcinol joints of CCA-treated and untreated southern pine. Forest Prod. J. 38(10): 59 63.

14. So, W. T. 2007. The Effects of Number and Location of Finger Joints on the Bending Strength of Glue Laminated Wood for Green Wood Building. Journal of Korea Furniture Society $18(1): 20 \sim 30$.

15. So, W. T. and J. K. Chai. 2005. Study on the manufacturing of high-frequency heating Japanese cedar laminated board by finger jointing method (1) - Gluing characteristics of Japanese cedar board by PVAc emulsion adhesives. Journal of Korea Furniture Society 16(1): $1 \sim 8$. 